\title{
Manajemen kompetensi dosen Universitas Muhammadiyah Jakarta
}

\author{
Saepudin ${ }^{*}$, Nanang Fattah ${ }^{2}$, Hendri Tanjung ${ }^{3}$, Akhmad Alim ${ }^{3}$ \\ Universitas Muhammadiyah Jakarta, Indonesia \\ Universitas Pendidikan Indonesia Bandung, Indonesia \\ Universitas Ibn Khaldun Bogor, Indonesia \\ *sasmintarasmintar@gmail.com
}

\begin{abstract}
The purpose of this research is to study and analyze the competency management of Universitas Muhammadiyah Jakarta lecturers. The theoretical approach used is the theory of lecturer competency management which refers to policies, programs, and techniques for implementing scientific competence, propagation competence, moral competence, and creed competence. This research method uses qualitative research methods by describing and analyzing the reality that occurs in the object under study which refers to the naturalistic paradigm by constructing the reality of research naturally. The findings show that the competence management of lecturers at the Universitas Muhammadiyah Jakarta is considered very effective by integrating academic and spiritual characters. The competency management of the Universitas Muhammadiyah Jakarta lecturers was analyzed through four aspects, namely the management of scientific competencies, the management of da'wah competencies, the management of moral competencies and the management of aqidah competencies.
\end{abstract}

Keywords: integration; lecturer competence; management

\begin{abstract}
Abstrak
Tujuan penelitian ini adalah untuk mengkaji dan menganalisis manajemen kompetensi dosen Universitas Muhammadiyah Jakarta. Pendekatan teori yang digunakan yaitu teori manajemen kompetensi dosen yang mengacu pada kebijakan, program dan teknik pelaksanaan kompetensi keilmuan, kompetensi dakwah, kompetensi akhlak dan kompetensi akidah. Metode penelitian ini menggunakan metode penelitian kualitatif yaitu dengan cara menggambarkan dan menganalisis tentang realitas yang terjadi pada objek yang diteliti yang mengacu pada paradigma naturalistis dengan cara mengonstruksi realitas penelitian secara alamiah. Hasil temuan penelitian menunjukkan bahwa manajemen kompetensi dosen Universitas Muhammadiyah Jakarta dinilai sangat efektif dengan mengintegrasikan karakter akademik dan karakter spiritual. Manajemen kompetensi dosen Universitas Muhammadiyah Jakarta dianalisis melalui empat aspek yaitu pengelolaan kompetensi keilmuan, pengelolaan kompetensi dakwah, pengelolaan kompetensi akhlak dan pengelolaan kompetensi akidah.
\end{abstract}

Kata Kunci: integrasi; kompetensi dosen; manajemen

Diserahkan: 11-05-2019 Disetujui: 30-10-2019 Dipublikasikan: 31-10-2019

Kutipan: Saepudin, S., Fattah, N., Tanjung, H., \& Alim, A. (2019). Manajemen kompetensi dosen Universitas Muhammadiyah Jakarta. Ta'dibuna: Jurnal Pendidikan Islam, 8(2), 311-325.

doi:http://dx.doi.org/10.32832/tadibuna.v8i2.1369 


\section{Pendahuluan}

Perguruan Tinggi berperan strategis dalam memobilisasi kader penerus bangsa yang memiliki kemampuan profesional, pemimpin sosial, pemimpin politik, pengusaha sukses. Oleh karena itu perguruan tinggi dituntut untuk dikelola secara profesional.

Modernisasi pendidikan tinggi merupakan suatu keharusan guna dapat mengadaptasikan dengan lingkungan global. Hal ini sebagaimana dinyatakan Parakhina, Godina, Boris dan Ushvitsky bahwa modernisasi pendidikan tinggi di Rusia dilakukan sebagai upaya untuk mencapai keberhasilan dalam mengintegrasikan dengan lingkungan pendidikan global. Namun, menurut Parakhina, Godina, Boris and Ushvitsky bahwa pada umumnya model manajemen kontemporer yang diterapkan universitas di Rusia dinilai kurang efisiensi. Hal ini disebabkan oleh kurangnya fleksibilitas strategi daya saing universitas di Rusia dan kurang efektifnya pengelolaan universitas akibat dari adanya konflik kepentingan pada level struktural universitas yang berpengaruh terhadap krisis manajemen universitas. Selama 25 tahun terakhir, telah terjadi perubahan radikal dalam pengembangan institusi pendidikan tinggi di Rusia pada anggaran pembiayaan, pangsa pasar dan lingkungan lokal. Oleh karena itu universitas dituntut untuk dikelola secara profesional agar menghasilkan produk yang inovatif sebagai upaya untuk meningkatkan daya saing global (Shujahat dkk., 2017)

Di Indonesia, penyelenggaraan pendidikan tinggi dilakukan oleh pemerintah, yaitu Perguruan Tinggi Negeri (PTN) dan oleh masyarakat yaitu, Perguruan Tinggi Swasta (PTS), baik dalam bentuk universitas, sekolah tinggi, institut, maupun akademi. Peran Perguruan Tinggi (PT) dalam memberikan jasa pendidikan tinggi semakin meningkat.

Perguruan Tinggi diupayakan mampu menghasilkan sumber daya manusia yang memiliki kemampuan akademik serta profesional dalam bidangnya. Namun, dalam kenyataannya menurut Tilaar,

"Pendidikan tinggi di Indonesia masih belum bermakna dalam peningkatan kualitas manusia Indonesia, baik moral, etos kerja, kemampuan dan keterampilan masih jauh dari harapan yang didambakan. Kehidupan global saat ini menuntut penguasaan dan penerapan ilmu pengetahuan dan teknologi, namun upaya pendidikan tinggi masih belum sepenuhnya memenuhi tuntutan-tuntutan tersebut, karena pendidikan tinggi kita sebagaimana dilaporkan dalam berbagai penelitian termasuk rendah di kawasan Asia (Purba, 2010).

Tuntutan normatif yang begitu tinggi bagi Perguruan Tinggi mengakibatkan Perguruan Tinggi dituntut untuk mampu mengemban misi pengembangan kemampuan penalaran individu sebagai salah satu kekuatan utama agar lulusannya memiliki kemampuan akademik dan dapat memenuhi kebutuhan industri.

Dosen adalah pendidik profesional dan ilmuwan yang tugas utamanya adalah untuk mentransformasikan, mengembangkan, dan menyebarkan pengetahuan, teknologi, dan seni melalui pendidikan, penelitian dan layanan masyarakat. Tetapi, pada kenyataannya, 
kompetensi dosen Perguruan Tinggi Islam Swasta (PTKIS) dinilai masih rendah, pendidikan dan pengajaran belum dilaksanakan secara profesional, produk riset dosen dinilai belum memenuhi harapan, kecerdasan spiritual, kecerdasan intelektual dan kecerdasan sosial dosen masih rendah. Menurut Suhaemi dan Aedi, bahwa faktor pemicu rendahnya kompetensi dosen pada perguruan tinggi swasta disebabkan oleh kebijakan perencanaan dan persiapan dosen masih lemah, pengembangan kompetensi dosen belum ditangani secara profesional sesuai dengan kebutuhan, mengabaikan kebutuhan mahasiswa, strategi manajemen peningkatan kompetensi dosen belum terkoordinasi dengan baik, dan pengembangan kompetensi profesional dosen terus menerus mengalami kegagalan (Suhaemi \& Aedi, 2015).

Peranan dosen sebagai pelaksana utama pendidikan di Perguruan Tinggi yang secara operasional merupakan pelaksana terdepan dalam pengelolaan pendidikan tinggi sangat menentukan keberhasilannya. Untuk itu, dosen dituntut secara aktif melakukan terobosan dan inovasi dalam melaksanakan Tri Darma Perguruan Tinggi Atas dasar pemikiran tersebut dosen dituntut untuk memiliki kompetensi dalam kegiatan pendidikan dan pengajaran, penelitian dan pengembangan, serta pengabdian pada masyarakat.

Universitas Muhammadiyah Jakarta merupakan salah satu Perguruan Tinggi Islam di Indonesia berperan strategis dalam upaya mencerdaskan bangsa dan sebagai aset masyarakat yang tumbuh dan berkembang dalam masyarakat bekerja sama dengan pemerintah. Seiring dengan pertumbuhan jumlah mahasiswa selama 4 tahun sejak tahun 2013 sampai dengan tahun 2017, bertambah sebanyak 5.815 (45,8 \%) dengan kenaikan jumlah rata-rata mahasiswa sebanyak 1.163 (11,63 \%) per tahun. (Data Dosen Tetap, Pusat Sumbar Daya Manusia Universitas Muhammadiyah Jakarta, Tahun 2017). Seiring dengan pertambahan jumlah mahasiswa, jumlah dosen mengalami pertambahan yang signifikan sesuai rasio dosen dan mahasiswa, pertambahan jumlah dosen Universitas Muhammadiyah Jakarta selama 5 tahun terakhir (2012 - 2017) sebanyak 280 (65, $82 \%$ ) dosen, dengan jumlah kenaikan rata-rata jumlah dosen sebanyak $56(13,14) \%$ per tahun. (Data Mahasiswa, Pusat Sumbar Daya manusia Universitas Muhammadiyah Jakarta, tahun 2017) Hal ini artinya pengelolaan Universitas Muhammadiyah Jakarta selama 5 tahun terakhir dinyatakan efektif.

Dalam upaya penguatan kompetensi dosen, Universitas Muhammadiyah menerapkan pola pengelolaan sumber daya manusia berlandaskan pada ajaran Islam dan kemuhammadiyahan. Pendekatan tersebut merupakan ciri utama dari Universitas Muhammadiyah Jakarta dalam membangun karakter dosen yang memiliki karakter spiritual dan karakter akademik yang terintegrasi dalam pemahaman dan pengamalan (Farihen, 2018). 
Untuk menghasilkan lulusan yang berkualitas, kreatif, inovatif dan profesional, penerapan manajemen kompetensi dosen dalam membangun karakter dosen yang memiliki karakter spiritual dan karakter akademik merupakan alternatif yang tepat pada lembaga pendidikan tinggi keagamaan Islam, tetapi dalam praktiknya mengalami banyak persoalan. Persoalan utama yang dihadapi oleh Perguruan Tinggi Islam Swasta (PTKIS) saat ini adalah kurang berhasilnya dalam mencapai dua tujuan pokok pendidikan tinggi yaitu masalah kualitas lulusan yang dihasilkannya dan sumbangan PTKIS pada pengembangan ilmu. Kurang-berhasilnya PTKIS dalam menunaikan tugas pokoknya, menurut Direktorat Jendral Kelembagaan Agama Islam disebabkan oleh manajemen PTKIS yang masih dikelola secara tradisional dengan modal semangat berjuang tanpa disertai dengan kemampuan mengelola sebuah perguruan tinggi secara modern (Direktorat Jendral Kelembagaan Agama Islam, 2011).

Universitas Muhammadiyah Jakarta, selain keberhasilannya dalam meningkatkan kuantitas dan kualitas lulusan, disisi lain terdapat kelemahan terkait dengan kompetensi dosen, khususnya terkait dengan pelaksanaan Tri Dharma perguruan tinggi yaitu: kegiatan pembelajaran masih dilakukan secara konvensional, kurang memanfaatkan media informasi dan teknologi digital, dosen kurang produktif dalam melakukan penelitian. Hal ini karena dosen lebih terkonsentrasi pada kegiatan pendidikan dan pengajaran. Selama 4 tahun terakhir yaitu tahun 2013 - 2017 sebanyak 290 judul penelitian dengan jumlah rata rata pertahun sebanyak 73 (14,9\%) hasil penelitian dosen yang dipublikasikan. Hal ini mengindikasikan bahwa kompetensi dosen dalam bidang penelitian dinilai sangat rendah sekali.

Berdasarkan latar belakang masalah, banyak faktor yang berpengaruh terhadap rendahnya kompetensi dosen PTKIS, penelitian ini difokuskan pada manajemen kompetensi dosen Universitas Muhammadiyah Jakarta

\section{Metodologi Penelitian}

Metode yang digunakan dalam penelitian ini adalah metode kualitatif. Metode kualitatif adalah jenis penelitian yang dilakukan untuk menggambarkan dan menganalisis tentang realitas yang terjadi pada objek yang diteliti. Menurut Denzin dan Lincoln, penelitian kualitatif merupakan penelitian yang memfokuskan pada multimethod yang melibatkan pendekatan interpretatif, naturalistis, pendekatan pada materi pokok. Hal ini berarti bahwa para peneliti kualitatif belajar dalam lingkungan alamiah, mencoba untuk memahami atau menafsirkan fenomena dalam arti makna yang dibawa orang kepada mereka (Denzin \& Lincoln, 1994). Berdasarkan karakteristik tersebut, menurut Sugiyono bahwa penelitian kualitatif itu: (a) Dilakukan pada kondisi yang alamiah, (sebagai lawannya adalah eksperimen), langsung ke sumber data dan peneliti adalah instrumen kunci, (b) penelitian kualitatif lebih bersifat deskriptif. Data yang terkumpul berbentuk kata-kata atau gambar, sehingga tidak menekankan pada angka, (c) 
penelitian kualitatif lebih menekankan pada proses daripada produk atau outcome, (d) Penelitian kualitatif melakukan analisis data secara induktif (Sugiyono, 2010).

Pengumpulan data dapat dilakukan dalam berbagai setting, berbagai sumber, dan berbagai cam. Bila dilihat dari settingnya, data dapat dikumpulkan pada setting alamiah (natural setting), Bila di lihat dari sumber datanya, maka pengumpulan data dapat menggunakan sumber primer, dan sumber sekunder. Sumber primer adalah sumber data yang langsung memberikan data kepada pengumpul data, dan sumber sekunder merupakan sumber yang tidak langsung memberikan data kepada pengumpul data, teknik pengumpulan data dapat dilakukan dengan observasi (pengamatan) interview (wawancara), dan studi dokumentasi. Dalam penelitian ini teknik pengumpulan data dilakukan dengan cara wawancara mendalam observasi, dan studi dokumentasi dan angket.

Sumber data primer adalah sumber data yang langsung memberikan data kepada peneliti, sedangkan sumber data sekunder adalah sumber data yang tidak langsung memberikan data kepada peneliti, seperti melalui dokumen maupun dengan memanfaatkan orang lain. Menurut Iskandar, bahwa sumber data utama dalam penelitian kualitatif yaitu kata-kata, dan tindakan, serta dokumen. Iskandar menyatakan bahwa kata-kata dan tindakan, merupakan sumber data utama dalam penelitian kualitatif, Sumber data tersebut dapat dicatat dengan catatan tertulis atau melalui rekaman video, rekaman tipe recorder, pengambilan foto atau kamera. Pencatatan sumber data utama. Sedangkan dokumentasi, merupakan data tambahan yang mendukung data utama yang didapatkan peneliti dari melihat, mendengar dan bertanya (Iskandar, 2009).

Data primer: dalam penelitian ini diperoleh melalui informan seperti: Pimpinan, dosen, Universitas Muhammadiyah Jakarta dan orang-orang yang mengetahui dan memahami objek penelitian. Sedangkan data sekunder berupa data-data yang sudah tersedia dan dapat diperoleh oleh peneliti, berupa data kegiatan Universitas Muhammadiyah Jakarta, foto dan dokumen yang mendeskripsikan keberadaan Universitas Muhammadiyah Jakarta.

Pemeriksaan didasarkan atas sejumlah kriteria tertentu. Menurut Moleong, pemeriksaan keabsahan data dapat dilakukan dengan beberapa cara yaitu: 1) perpanjangan keikutsertaan, 2) ketekunan pengamatan, 3) pengecekan keabsahan data, 4) pengecekan anggota, 5) kecukupan referensi, 6) kajian kasus negatif, dan 7) pengecekan sejawat (Moleong, 2010).

Analisis data dilakukan melalui penerapan model analisis interaktif. Model ini melibatkan tiga komponen yang saling terkait dan menentukan hasil akhirnya, yaitu reduksi data, sajian data dan kesimpulan atau verifikasi . 


\section{A. Hasil Penelitian}

\section{Hasil dan Pembahasan}

Pengelolaan kompetensi dosen Universitas Muhammadiyah Jakarta merupakan aspek yang penting dan strategis yang diimplementasikan dalam pelaksanaan Tri Dharma Perguruan Tinggi. Manajemen kompetensi dosen adalah kebijakan, program, dan teknis pelaksanaan penguatan kompetensi dosen yang mengacu pada ajaran Islam dan kemuhammadiyahan dalam mewujudkan kampus Islami merupakan kebijakan, program dan kegiatan yang ideal untuk menghasilkan lulusan yang beriman, berakhlak, profesional, mandiri, kreatif, inovatif dan memiliki daya saing pada pasar kerja baik di lingkungan domestik maupun internasional

Kebijakan, jenis program dan implementasi kompetensi dosen Universitas Muhammadiyah Jakarta, meliputi: pengelolaan kompetensi keilmuan, kompetensi dakwah, kompetensi akhlak, dan kompetensi akidah.

\section{Pengelolaan Kompetensi Keilmuan}

Pengelolaan kompetensi keilmuan dosen di Universitas Muhammadiyah Jakarta dilaksanakan melalui rekrutmen, seleksi dan penempatan kriteria penentuan, meliputi kriteria akademik berupa minimal pendidikan S2 (strata dua) dari institusi yang bereputasi baik, dengan IPK minimal 3,00. tes Al-Islam dan Kemuhammadiyahan, Tes Potensi Akademik, tes psikologi, presentasi ilmiah, dan wawancara. Dalam kaitan ini Rohimi menyatakan bahwa pengelolaan kompetensi keilmuan dosen tetap Universitas Muhammadiyah Jakarta, diawali dari pemenuhan kebutuhan berdasarkan jumlah rasio dosen dan mahasiswa, rekrutmen, seleksi dan penetapan, serta percobaan untuk dilakukan penilaian kinerja profesional. Dalam serangkaian prosedur penerimaan dosen, merupakan tahap awal untuk menjaring dosen tetap dilihat dari kompetensi keilmuannya, yang di dalamnya meliputi: jenjang pendidikan, kemampuan akademik, pemahaman dan pengamalan Al Islam dan kemuhammadiyahan . (Zam Zami Rohimi, Wawancara Pribadi, 2018)

Menurut Rohimi bahwa serangkaian prosedur untuk pengangkatan dosen tetap merupakan langkah awal dari pengelolaan kompetensi dosen untuk melihat tingkat kompetensi keilmuannya. Setelah menjadi dosen tetap, diwajibkan untuk memenuhi kewajibannya sesuai dengan Beban Kerja Dosen yang dapat dijadikan bahan laporan kegiatan akademik dalam setiap semester. Dari kegiatan akademik dosen berdasarkan standar Beban Kerja Dosen, dapat dijadikan acuan untuk melihat kinerja kompetensi keilmuan dosen dalam bidang pendidikan dan pengajaran, penelitian dan pelatihan, serta pengabdian masyarakat (Rohimi, 2018).

Upaya penguatan kompetensi keilmuan dosen, menurut Rohimi dosen tetap dituntut untuk mengikuti berbagai kegiatan pendukung penguatan kompetensi keilmuan dosen, seperti studi lanjut jenjang akademik dosen, kegiatan pelatihan penelitian untuk penulisan hasil karya ilmiah, penulisan jurnal nasional dan International, penguatan 
pengajaran berbasis digital, strategi efektivitas pengajaran berbasis metode dan berbagai kegiatan pendukung penguatan kompetensi keilmuan lainnya (Rohimi, 2018).

Demikian pula menurut Siti Masithoh bahwa upaya membangun penguatan kompetensi dosen dimulai dari rekrutmen, seleksi, dan penetapan dosen, kemudian peningkatan penguatan kompetensi dosen difokuskan pada penguatan kompetensi Catur Dharma perguruan tinggi. Penguatan kompetensi keilmuan tersebut dilaksanakan dengan berbagai kegiatan yang mendukung penguatan kompetensi keilmuan dosen, seperti studi lanjut, seminar, workshop dan pelatihan yang terkait dengan pendidikan dan pengajaran, penelitian dan pengembangan, dan pengabdian pada masyarakat. Kegiatan tersebut diadakan di kampus dan di luar kampus. Lebih lanjut Masithoh menyatakan bahwa dalam upaya penguatan kompetensi dosen dalam kegiatan penelitian, publikasi hasil penelitian melalui penulisan jurnal ilmiah nasional dan International dan penulisan buku ajar, setiap dosen diberikan dana stimulus yang dianggarkan dari anggaran pembiayaan universitas (Masithoh, 2018).

Farihen menyatakan bahwa upaya pemantapan penguatan kompetensi keilmuan dosen, untuk dosen baru yang telah menjalani serangkaian prosedur seleksi dan penetapan diwajibkan mengikuti kegiatan Darul Arqam. Dalam hal ini lembaga AIK mengambil bagian dalam bentuk pelaksanaan kegiatan Darul Arqam, yang dilaksanakan selama 3 hari dua malam, dengan materi pembekalan akidah, akhlak, integrasi keilmuan dan kemuhammadiyahan. Instruktur pembekalan yang ditugaskan adalah dosen-dosen senior dan pakar keilmuan dari Pengurus Pusat Perserikatan Muhammadiyah. Kegiatan tersebut menurut Farihen, bertujuan untuk membekali pemahaman dan pengamalan alIslam dan kemuhammadiyahan. Sehingga out put dari pembekalan kaderisasi dalam kegiatan Darul Arqam adalah dosen yang memiliki dasar keilmuan yang Islami yang kuat sebagai pelaksana utama yang dapat mentransformasikan ilmunya kepada mahasiswa melalui pelaksanaan tugas dan fungsinya sebagai dosen (Farihen, 2018). Tahap-tahap prosedur penerimaan dosen Tetap, Menurut, Kahar merupakan bagian dari wujud pengelolaan kompetensi keilmuan dosen yang dilaksanakan berdasarkan ketetapan peraturan Universitas Muhammadiyah Jakarta (Maranjaya, 2018)

Sebelum ditetapkan menjadi dosen Universitas Muhammadiyah, menurut Dr. Farihen MA, selaku Direktur Lembaga AIK, bahwa dosen baru diwajibkan mengikuti kegiatan Al-Islam Kemuhammdiyahan yang dilaksanakan oleh Lembaga AIK, kegiatan tersebut diadakan selama 3 hari 2 malam, dengan materi mencakup: Aqidah Akhlak, Ibadah, Islam ditinjau dari berbagai aspek, dan kemuhammadiyahan. Kegiatan tersebut merupakan pengenalan awal tentang Al-Islam dan kemuhammadiyahan (Farihen, 2018). Menurut Farihen, Lembaga AIK memiliki dasar perjuangan: (1) Al-Qur'an dan Sunnah Rasulullah menjadi landasan berpikir, bersikap dan berperilaku, (2) Tauhid adalah basis nilai pengembangan institusi Perguruan Tinggi Muhammadiyah (PTM), (3) Ideologi 
Muhammadiyah merupakan acuan sikap, kebijakan dan perilaku PTM, (4) PTM adalah media dakwah Perserikatan Muhammadiyah, (5) PTM dikelola sesuai dengan pedoman, ketentuan dan kaidah-kaidah yang ditetapkan oleh PP Muhammadiyah dan Majelis Direktorat Pendidikan Tinggi Penelitian dan Pengembangan dan SK Rektor No. 520/2015 Caturdharma AIK (Farihen, 2018).

Standar kelembagaan AIK meliputi: (1) ketentuan tentang pengelolaan bidang AIK diatur dalam Statuta UMJ, (2) UMJ memiliki Wakil Rektor yang membidangi dan bertanggung jawab mengelola AIK dan pengembangan Kampus Islami, (3) untuk melaksanakan tugas-tugas operasional bidang AIK dan pengembangan kampus Islami, setiap UMJ harus memiliki lembaga pengkajian dan pengembangan AIK (LPP-AIK). (Tim Penyusun, 2017)

Semua dosen tetap UMJ memiliki jenjang akademik S2 sesuai dengan tuntutan undang-undang sistem pendidikan nasional tahun 2005 yaitu sebanyak 78 \% (499), jenjang akademik S3 22 \% (69). Hal ini menunjukkan bahwa dosen tetap UMJ dilihat dari jenjang akademik dinilai sangat baik, karena $100 \%$ dinyatakan sudah memenuhi tuntutan undang-undang sistem pendidikan nasional. Sebagian besar dosen memiliki pangkat akademik $68 \%$, (369), tidak memiliki pangkat akademik (TP) $34 \%$, (199), dengan perincian Asisten Ahli (AA) $24 \%$, Lektor (L) sebesar 32 \%, Lektor Kepala (LK) sebesar 8 \%, Guru Besar (Prof) sebesar $2 \%$. Perkembangan dosen tahun 2012 sampai dengan 2017 mengalami pertumbuhan sebesar $65 \%$, dengan kenaikan rata-rata per tahun sebesar $13 \%$. Sejalan dengan pertumbuhan jumlah mahasiswa sebesar 64\%.dengan kenaikan rata-rata 12,8 \% per tahun.

\section{Pengelolaan Kompetensi Dakwah}

Menurut Farihen, "pengelolaan kompetensi dakwah dosen Universitas Muhammadiyah Jakarta merupakan aspek penting dan strategis untuk mewujudkan kampus Islami. Hal ini sejalan dengan semangat perjuangan Perserikatan Muhammadiyah untuk melakukan Islamisasi melalui kegiatan dakwah". (Farihen Wawancara Pribadi, 2018). Sejalan dengan pendapat tersebut Irfan menyatakan bahwa pengelolaan kompetensi dakwah untuk dosen tetap difokuskan pada pemahaman dan implementasi dakwah melalui kegiatan perkuliahan, penelitian dan pengabdian pada masyarakat. Hal ini merupakan implementasi dari kecakapan dosen dalam kegiatan dakwah dengan lisan, tulisan dan tindakan. Ketiga aspek kegiatan dosen tersebut, merupakan kegiatan utama dosen yang bisa dijadikan sebagai sarana dakwah untuk mentransformasikan nilai-nilai Islam kepada mahasiswa sebagai subjek yang menjadi sasaran kegiatan dakwah (Farihen, 2018).

Pengelolaan kompetensi dakwah dosen dilakukan melalui kegiatan perkuliahan yaitu sebanyak 73,33\% responden menyatakan bahwa kurikulum merupakan acuan dalam kegiatan perkuliahan berperan penting dalam sebagai media dakwah yaitu dengan 
memasukkan nilai-nilai keimanan, ketakwaan, akhlak dan jihad melalui dakwah ke dalam kurikulum. Terdapat 4 mata kuliah al-Islam dan kemuhammadiyahan yaitu mata kuliah Aqidah, akhlak, integrasi Ilmu, dan kemuhammadiyahan. Masing-masing mata kuliah memiliki bobot 2 Satuan Kredit Semester.

Pengelolaan kompetensi dakwah untuk dosen tetap Universitas Muhammadiyah Jakarta difokuskan pada pemahaman dan implementasi dakwah melalui kegiatan perkuliahan, penelitian dan pengabdian pada masyarakat. Hal ini merupakan implementasi dari kecakapan dosen dalam kegiatan dakwah dengan lisan, tulisan dan tindakan. Ketiga aspek kegiatan dosen tersebut, merupakan kegiatan utama dosen yang bisa dijadikan sebagai sarana dakwah untuk mentransformasikan nilai-nilai Islam kepada mahasiswa sebagai subjek yang menjadi sasaran kegiatan dakwah.

\section{Pengelolaan Kompetensi Akhlak}

Pengelolaan kompetensi akhlak dosen mengacu pada al-Islam dan Kemuhammadiyahan yang pelaksanaannya di delegasikan pada Direktur Lembaga AIK pada tingkat Universitas, tingkat Fakultas diserahkan pada Dekan di Fakultas masingmasing di Universitas Muhammadiyah Jakarta yang dilakukan melalui kegiatan Darul Arqam, Kegiatan Darul Arqam pesertanya adalah dosen dan karyawan yang dilaksanakan satu tahun sekali, tepanya setiap akhir tahun, materi yang diberikan mencakup: akidah, akhlak, Islam ditinjau di berbagai aspek, dan kemuhammadiyahan, instruktur yang bertugas pada kegiatan Darul Arqam adalah dosen-dosen Universitas Muhammadiyah yang memiliki sertifikat AIK dan dinyatakan sudah layak menjadi instruktur dilihat dari penguasaan materi, akhlak dan sikap tauhidnya ditambah instruktur dari Perserikatan Muhammadiyah. Tujuan kegiatan Darul Arqam memberikan bekal tentang Al-Islam dan Kemuhammadiyahan dengan memberikan penguatan akidah akhlak, integrasi keilmuan, dan kemuhammadiyahan untuk membentuk kepribadian yang sejalan dengan ajaran Islam guna mewujudkan kampus Islami.

Menurut Rohimi Zam Zami bahwa pengelolaan kompetensi akhlak dosen Universitas Muhammadiyah Jakarta, mengacu pada al-Islam dan Kemuhammadiyahan, pelaksanaannya di delegasikan pada Direktur Lembaga AIK pada tingkat Universitas, dan pada tingkat Fakultas diserahkan pada Dekan Fakultas (Rohimi, 2018). Kegiatan pengelolaan kompetensi akhlak pada tingkat Universitas dilaksanakan oleh lembaga AIK di bawah pengelolaan direktur AIK dengan nama kegiatan Darul Arqam, Menurut Kegiatan Darul Arqam yang dilaksanakan pada tingkat Universitas pesertanya adalah semua pimpinan, dosen dan karyawan Universitas Muhammadiyah Jakarta (Farihen, 2018). Kegiatan Darul Arqam untuk dosen dan karyawan dilaksanakan satu tahun sekali, tepanya setiap akhir tahun, materi yang diberikan mencakup: akidah, akhlak, Islam ditinjau di berbagai aspek, dan kemuhammadiyahan, instruktur yang bertugas pada kegiatan Darul Arqam adalah dosen-dosen Universitas Muhammadiyah yang memiliki sertifikat AIK dan dinyatakan sudah layak menjadi instruktur dilihat dari penguasaan 
materi, akhlak dan sikap tauhidnya ditambah instruktur dari Perserikatan Muhammadiyah.

Tujuan kegiatan Darul Arqam, menurut Rohimi, yaitu memberikan bekal tentang AlIslam dan Kemuhammadiyahan dengan memberikan penguatan akidah akhlak, integrasi keilmuan, dan kemuhammadiyahan untuk membentuk kepribadian yang sejalan dengan ajaran Islam guna mewujudkan kampus Islami. Materi penguatan kompetensi akhlak dosen dalam kegiatan Darul Arqam difokuskan pada upaya menginternalisasikan nilainilai akhlak Rosul kepada dosen yaitu sifat fathonah, tabligh, sidik dan amanah. Empat karakter akhlak Rosul tersebut agar dapat dijiwai oleh dosen dan menjadi acuan dosen dalam melaksanakan tugasnya (Rohimi, 2018).

Pengelolaan kompetensi akhlak Dosen Universitas Muhammadiyah Jakarta dari hasil temuan survei menunjukkan sebanyak $85 \%$ dosen menyatakan dalam melaksanakan tugasnya, dosen dituntut untuk memiliki sifat cerdas, pandai, mampu memahami, menghayati dalam melaksanakan tugasnya dengan baik, kreatif dan inovatif sebagai sifat dasar yang berpengaruh langsung terhadap kemajuan perguruan tinggi tempat tugasnya dan $80 \%$ menyatakan kejujuran merupakan landasan etik dosen yang harus diprioritaskan dalam melaksanakan tugasnya dan merupakan tanggung jawab moral dosen dalam kegiatan pengajaran, penelitian dan pengabdian pada masyarakat.

Dosen dituntut untuk dapat menyampaikan kebenaran dan menjauhi segala larangan Allah secara bersungguh-sungguh untuk mencari jalan yang baik dalam mewujudkan kemaslahatan umatnya di dunia dan akhirat, sebanyak 81,67\% dosen menyatakan bahwa dosen diwajibkan menyampaikan kebaikan dan menjauhi segala larangan Allah, 88,33 \% dosen menyatakan bahwa dosen dituntut untuk memiliki sifat amanah, fathonah, tablig dan shiddiq dalam melaksanakan tugasnya dalam upaya membangun kualitas mahasiswa yang berakhlakul karimah.

\section{Pengelolaan Kompetensi Aqidah}

Pekerjaan sebagai dosen merupakan panggilan Allah SWT, sehingga dosen dalam melaksanakan tugasnya sebagai realisasi Tri Darma perguruan tinggi dituntut untuk senantiasa dilandasi oleh sikap sabar, ikhlas dan mengharap ridho Allah. Hal ini sebagaimana dinyatakan Rohimi bahwa dalam pelaksanaan tugas dan tanggung jawabnya dosen Universitas Muhammadiyah dituntut untuk memahami, menghayati dan mampu mengamalkan nilai-nilai akidah, dimana bahwa pelaksanaan tugas dan tanggung jawab dosen merupakan realisasi dari peningkatan keimanan terhadap Allah, sehingga implementasi Tri Dharma perguruan tinggi merupakan panggilan dari Allah SWT dengan mendasarkan pada keridloaan, keikhlasan dan kesabaran sebagai fondasi akidah dosen (Rohimi, 2018). Implementasi kompetensi akidah dosen merupakan aspek yang penting yang harus diutamakan oleh dosen dalam menjalankan profesinya dengan menganggap 
bahwa bekerja sebagai dosen merupakan panggilan Ilahi Rabbi yang dilandasinya adanya sikap lapang dada, ikhlas dan sabar (Farihen, 2018).

Sementara Susilahati menyatakan dalam upaya penguatan kompetensi akidah, LPPM berperan signifikan dalam mengelola kompetensi akidah dosen melalaui upaya menginternalisasikan nilai-nilai akidah dalam produk hasil penelitian dan kegiatan pengabdian masyarakat sebagai wujud dari implementasi ibadah. Begitu pula menurut Rika, mengakui bahwa selama bertugas menjadi dosen di Universitas Muhammadiyah Jakarta menganggap bahwa kerja merupakan bagian dari panggilan Allah (Sa'diyah, 2018).

Sejalan dengan pendapat tersebut Farihen menyatakan bahwa dalam upaya membangun etika kerja yang profesional untuk dosen Universitas Muhammadiyah Jakarta, dosen dituntut untuk dapat mengimplementasikan nilai-nilai ibadah dalam melaksanakan tugasnya sebagai wujud dari pemahaman dan pengamalan al-Islam dan Kemuhammadiyahan (Farihen, 2018). Sejalan dengan pandangan tersebut, Kahar menyatakan bahwa dalam rangka membangun kampus Islami, semua civitas akademika dituntut untuk menjadikan kampus sebagai sarana pengamalan Ibadah kepada Allah dengan mengutamakan keikhlasan dan kesabaran dalam melaksanakan tugas dan tanggung jawabnya (Maranjaya, 2018).

Pengelolaan kompetensi akidah merupakan aspek penting dalam membangun produktivitas kerja dosen. Sebesar 93,33 \% dosen menganggap bahwa semangat kerja yang dilandasi dengan keikhlasan akan menghasilkan kerja yang produktif, bekerja merupakan panggilan Allah SWT, sehingga dalam melaksanakan tugas Tri Darma perguruan tinggi senantiasa dilandasi oleh sikap sabar, ikhlas dan semata-mata karena mengharap ridho Allah, dan 81,66\% dosen menyatakan dalam melaksanakan tugas Tri Darma perguruan tinggi semata-matan karena mengharapkan ridho Allah.

Pengelolaan kompetensi dosen Universitas Muhammadiyah Jakarta meliputi: kompetensi keilmuan, kompetensi dakwah, kompetensi akhlak dan kompetensi akidah. Pengelolaan kompetensi dosen merupakan aspek penting dalam upaya meningkatkan sistem pelayanan kepada mahasiswa dalam mengembangkan nilai-nilai Islam kepada generasi mendatang dan bagi semua civitas akademika diupayakan dapat berperan aktif dalam upaya pengembangan dan peningkatan mutu Universitas Muhammadiyah Jakarta memalui peningkatan kompetensi dosen dengan mengintegrasikan karakter spiritual dan karakter akademik sebagai upaya dalam mewujudkan universitas Islami, modern dan terkemuka.

Manajemen kompetensi dosen yang mengacu pada integrasi penguatan karakter spiritual dan pengembangan karakter akademik merupakan pendekatan strategis dalam upaya membangun Perguruan Tinggi Keagamaan Islam yang bermutu, memiliki daya saing dalam menghadapi persaingan pasar industri. 


\section{B. Pembahasan}

Pengelolaan kompetensi keilmuan dosen merupakan aspek yang diprioritaskan, karena kompetensi keilmuan dosen merupakan syarat utama yang harus dimiliki oleh dosen sebelum memiliki legalitas profesional dosen.

Penentuan dosen merupakan tuntutan kebutuhan, karena adanya peningkatan minat dan kepercayaan masyarakat yang signifikan tiap tahunnya. Oleh karena itu, pihak Universitas Muhammadiyah Jakarta diupayakan untuk melakukan rekrutmen dosen dilakukan secara terbuka dan kompetitif untuk mencari bibit yang berkualitas sesuai dengan kebutuhan yang sejalan dengan pengembangan kampus terkemuka, modern dan Islami.

Promosi rekrutmen dosen diupayakan dipublikasikan secara terbuka dan memiliki daya jangkau yang luas sebagai cara yang lebih selektif menghimpun bibit - bibit yang mampu mengemban tugasnya untuk membawa Universitas Muhammadiyah menjadi Universitas Terkemuka, modern dan Islami pada tahun 2025 mendatang baik pada lingkup domestik maupun internasional.

Dalam pengelolaan kompetensi keilmuan dilakukan dengan cara uji coba kelayakan dan kepatutan dosen dengan menugaskan dosen untuk melaksanakan tugasnya sebagai pendidik, pengajar, peneliti dan mampu mengabdikan ilmunya pada masyarakat.

Pengelolaan kompetensi dakwah dilakukan melalui kebijakan, program dan kegiatan pengajaran sebagai wujud dari implementasi dakwah bil lisan, publikasi ilmiah hasil penelitian sebagai wujud dari dakwah bil kalam dan pengabdian masyarakat sebagai dakwah bil hal.

Dalam upaya meningkatkan kompetensi dakwah bil lisan melalui kegiatan pengajaran, maka dosen dituntut untuk mampu meningkatkan penghayatan dan pengamalan serta mampu menanamkan nilai-nilai keislaman kepada mahasiswa melalui penyampaian materi, penggunaan media, metode dan strategi yang sesuai dengan kebutuhan perkembangan mahasiswa.

Kegiatan perkuliahan merupakan kegiatan yang strategis untuk menginternalisasikan nilai-nilai keimanan dan ketakwaan kepada mahasiswa agar tertanam keyakinan yang kuat bahwa belajar merupakan kewajiban yang ditetapkan dalam ajaran Islam.

Dalam upaya untuk meningkatkan kompetensi dakwah bil kalam, dosen dituntut untuk dapat meningkatkan kegiatan riset-riset ilmiah yang hasilnya merupakan kreasi yang inovatif yang dapat memberikan kontribusi positif untuk mengatasi berbagai persoalan masyarakat dan bangsa menuju masyarakat dan bangsa yang maju, mandiri, kompetitif dan terhormat di mata dunia internasional. Berbagai hasil riset-riset ilmiah dosen diupayakan untuk dapat dipublikasikan dalam berbagai bentuk media publikasi, buku, jurnal dan artikel. 
Meningkatkan kompetensi dakwah bil hal, dosen Universitas Muhammadiyah Jakarta dapat meningkatkan pengabdian masyarakat melalui berbagai kegiatan yang dapat dirasakan langsung oleh masyarakat, seperti pembinaan desa-desa tertinggal, pembinaan lembaga-lembaga pendidikan, membantu meningkatkan produktivitas petani, peternak, nelayan, membentuk rumah pintar, rumah yatim, rumah sehat dan sebagainya. Berbagai kegiatan tersebut merupakan realisasi dari kompetensi dakwah bil hal.

Akhlak yang baik merupakan aspek yang utama yang harus dimiliki oleh dosen Universitas Muhammadiyah Jakarta, dalam pengelolaan kompetensi akhlak dosen, dosen dituntut untuk memiliki sifat fathanah, tabliq, amanah dan sidik yang direalisasikan dalam kegiatan pendidikan dan pengajaran, penelitian dan pengembangan dan pengabdian pada masyarakat.

Fathanah adalah bagian dari akhlak Rasulullah SAW yang harus diteladani oleh dosen dalam meningkatkan kompetensi akhlaknya. Oleh karena itu dosen dituntut untuk dapat meningkatkan kecerdasan dan kepandaianya untuk menjadi seorang akademisi yang profesional melalui berbagai kegiatan penguatan kompetensi dosen.

Dalam upaya meningkatkan kompetensi akhlak dosen, dosen Universitas Muhammadiyah Jakarta dituntut untuk dapat memiliki sifat tablig yaitu memuliki kecakapan dalam menyampaikan kebaikan dan cakap untuk mencegah perbuatan yang buruk yang diimplemantasikan pelaksanaan tugasnya sebagai pendidik dan pengajar, peneliti dan pengabdi pada masyarakat.

Sifat amanah adalah salah satu karakter sifat Rasul yang harus diteladani oleh dosen dalam upaya meningkatkan kompetensi akhlaknya untuk senantiasa dapat dipercaya dalam melaksanakn tugasnya dalam kegiatan mengajar dan mendidik, meneliti dan mengabdi pada masyarakat.

Dalam upaya meningkatan kompetensi akhlak dosen, maka dosen dituntut untuk memiliki kompetensi aqidah yaitu dosen untuk dapat meningkatkan keimanan dan ketaqawaan kepada Allah dengan menjadikan kerja semata-mata merupakan panggilan dari Allah, sehingga dalam melaksanakan tugasnya sebagai dosen, dosen akan merasa terbebas dari berbagai tekanan, karena dalam bekerja dosen selalu dilandasi oleh sifat sabar, ikhlas dan tawadhu, karena kerja bagi dosen yang memiliki kompetensi aqidah nya kuat akan merasa bahwa kerja semata-mata karena mencari ridho Allah.

Hakikat manusia dalam Islam terletak pada kerja kerasnya, dengan kerja manusia dapat melihat karyanya. Karya itulah sebagai identitas manusia yang diaktualisaikan dan manusia menjadi dikenal karena karyanya. Dari hal tersebut, dosen dituntut untuk terus bekerja sebagai wujud dari pengamalan ibadah, dengan kerja akan menghasilkan karya yang bisa memberikan manfaat bagi manusia lain. 


\section{Kesimpulan}

Berdasarkan temuan dan pembahasan hasil penelitian dapat dirumuskan kesimpulan sebagai berikut: pertama, Pengelolaan Kompetensi Keilmuan Dosen Universitas Muhammadiyah Jakarta dilakukan melalui analisis kebutuhan, rekrutmen, seleksi dan penetapan. Kriteria seleksi dosen tetap meliputi kriteria akademik berupa minimal pendidikan S2 (strata dua) dari institusi yang bereputasi baik, IPK minimal 3,00 dan berpengalaman dalam bidang profesinya. Diwajibkan mengikuti serangkaian tes, mencakup Tes Potensi Akademik, tes psikologi, presentasi ilmiah, tes Al-Islam Kemuhammadiyahan dan wawancara. Kedua, pengelolaan kompetensi dakwah dosen Universitas Muhammadiyah Jakarta dilakukan melalui kebijakan, program dan kegiatan pengajaran sebagai wujud dari implementasi dakwah bil lisan, publikasi ilmiah hasil penelitian dosen sebagai wujud dari dakwah bil kalam dan pengabdian masyarakat sebagai dakwah bil hal.

Dalam upaya meningkatkan kompetensi dakwah bil lisan melalui kegiatan perkuliahan. Kegiatan dakwah melalui kegiatan perkuliahan merupakan kegiatan yang strategis untuk menginternalisasikan nilai-nilai keimanan dan ketakwaan kepada mahasiswa.

Dalam upaya untuk meningkatkan kompetensi dakwah bil kalam, dosen Universitas Muhammadiyah Jakarta dituntut untuk dapat meningkatkan kegiatan riset-riset ilmiah yang hasilnya merupakan kreasi yang inovatif yang dapat memberikan kontribusi positif dan realistis untuk mengatasi berbagai persoalan masyarakat dan bangsa menuju masyarakat dan bangsa yang maju, mandiri, kompetitif dan terhormat di mata dunia internasional. Ketiga, Pengelolaan kompetensi akhlak dosen melalui kegiatan pendidikan dan pengajaran, penelitian dan pengembangan serta pengabdian pada masyarakat. Dalam upaya meningkatkan pengelolaan kompetensi akhlak dosen, dosen dituntut untuk memiliki 4 sifat karakter Rasulullah SAW yaitu sifat fatanah, tabli, amanah dan sidik yang direalisasikan dalam kegiatan pendidikan dan pengajaran, penelitian dan pengembangan dan pengabdian pada masyarakat.

Keempat, pengelolaan kompetensi akidah dosen dilakukan sebagai upaya untuk dapat meningkatkan keimanan dan ketakwaan kepada Allah dengan menjadikan kerja semata-mata merupakan panggilan dari Allah, sehingga dalam melaksanakan tugasnya n, dosen akan merasa terbebas dari berbagai tekanan, karena dalam bekerja dosen selalu dilandasi oleh sifat sabar, ikhlas dan tawadhu, karena kerja bagi dosen yang memiliki kompetensi akidahnya kuat akan merasa bahwa kerja semata-mata karena mencari ridho Allah.

\section{Daftar Pustaka}

Denzin, N. K., \& Lincoln, Y. S. (1994). Handbook of qualitative research. Sage Publications. Direktorat Jendral Kelembagaan Agama Islam. (2011). Memetakan persoalan perguruan 
tinggi agama Islam. Jakarta: Depag RI.

Farihen. (2018, Februari 13). Direktur Al-Islam dan Kemuhammadiyahan [Wawancara pribadi].

Iskandar. (2009). Metodologi Penelitian Kualitatif. Jakarta: Gaung Persada.

Maranjaya, K. (2018, Januari 17). Wakil Rektor I Bidang Akademik [Wawancara pribadi].

Masithoh, S. (2018, Januari 17). Dosen FAI [Wawancara pribadi].

Moleong, L. (2010). Metodologi Penelitian Kualitatif. Bandung: Remaja Rosdakarya.

Purba, S. (2010). Kinerja Pimpinan Jurusan di Perguruan Tinggi. Yogyakarta: LaksBang Pressindo.

Rohimi, Z. Z. (2018, Januari 17). Wakil Rektor IV Bidang Al-Islam dan Kemuhammadiyahan [Wawancara pribadi].

Sa'diyah, R. (2018, Februari 15). Dosen FAI [Wawancara pribadi].

Shujahat, M., Hussain, S., Javed, S., Malik, M. I., Thurasamy, R., \& Ali, J. (2017). Strategic management model with lens of knowledge management and competitive intelligence. VINE Journal of Information and Knowledge Management Systems, 47(1), 55-93. https://doi.org/10.1108/VJIKMS-06-2016-0035

Sugiyono. (2010). Metode penelitian kuantitatif dan R\&D. Bandung: Alfabeta.

Suhaemi, M. E., \& Aedi, N. (2015). A Management Strategy for the Improvement of Private Universities Lecturers' Professional Competences. International Education Studies, 8(12), 241-254. 